\title{
Construction and Operation of the Fehmarn Belt Immersed Tunnel Is a High-Risk Business Case
}

\author{
Hans Schjær-Jacobsen \\ RD\&I Consulting, Hellerup, Denmark \\ Email: hansschj@gmail.com
}

How to cite this paper: Schjær-Jacobsen, H. (2017). Construction and Operation of the Fehmarn Belt Immersed Tunnel Is a High-Risk Business Case. Journal of Financial Risk Management, 6, 1-15. https://doi.org/10.4236/jfrm.2017.61001

Received: January 5, 2017

Accepted: February 11, 2017

Published: February 14, 2017

Copyright $\odot 2017$ by author and Scientific Research Publishing Inc. This work is licensed under the Creative Commons Attribution International License (CC BY 4.0).

http://creativecommons.org/licenses/by/4.0/

\begin{abstract}
The Fehmarn Belt immersed tunnel project conditionally approved by the Danish parliament on 28 April 2015 is supposed to be built and commercially operated by a Danish state owned company and financed by loans guaranteed by the Danish government. The loans are going to be amortized by incomes from the tunnel users. According to plans construction work was supposed to start by 2016 followed by tunnel inauguration in 2022, this has been put on hold awaiting clarification of major uncertainty issues. Since the official financial model is publicly unavailable, the uncertainty profiles presented in this paper are based on a financial model developed by the author covering 60 years of future tunnel operation and validated in terms of project payback period (PBP) compared to published results generated by the official model. Uncertainty is represented and calculated by probabilistic uncertainty representation and Monte Carlo simulation as well as interval analysis. The resulting project uncertainty profiles are presented in terms of a traffic light metaphor: Green light corresponds to a payback period less than 40 years, yellow to $40-50$ years, and red to larger than 50 years. It turns out that the tunnel project constitutes a high-risk business case and the likelihood of financial project failure in terms of the payback period being outside of the green light zone is substantially larger than acknowledged by the project proponents and presented to the public. This is primarily due to apparently too optimistic base case assumptions of critical, but uncertain, project variables and methodologically insufficient partial sensitivity analyses.
\end{abstract}

\section{Keywords}

Fehmarn Belt, Uncertainty Profile, Probabilistic Representation, Monte Carlo Simulation, High-Risk, Business Case 


\section{Introduction}

By February 25, 2015, the Danish Minister of Transport on behalf of the socialliberal Government proposed a Construction Act L141 (Danish Parliament, 2015) concerning construction and operation of an immersed tunnel connection crossing Fehmarn Belt between Denmark at Rødby and Germany at Puttgarden. Preparatory construction work was already under way according to the Planning Act (Danish Parliament, 2009).

The Fehmarn Belt immersed tunnel is a visionary endeavor and a technological marvel. It is approximately $18 \mathrm{~km}$ long and will consist of individual elements that will be manufactured on land at a production site specifically constructed for the purpose at Rødbyhavn. There are two types of tunnel elements: 79 standards and 10 special elements. Each of the standard elements is approximately $217 \mathrm{~m}$ long, $42 \mathrm{~m}$ wide and $9 \mathrm{~m}$ high. One element weighs around 72,000 tons. The financing of the Fixed Link across the Fehmarn Belt is based on a state guarantee model. This model entails financing of the project via loans guaranteed by the Danish Government and which are to be repaid via revenue from the users of the Fixed Link. These and further details of the Fehmarn Belt immersed tunnel project are available from the project company (Femern A/S, 2016) fully owned by the state company Sund \& Bælt Holding A/S.

The Fehmarn Belt immersed tunnel project is the third in a row of large Danish infrastructure projects supported by a great majority of political parties in the Parliament. The first one was the Great Belt fixed link comprising two bridges and a tunnel inaugurated in 1997-1998 that turned out to become a big financial success due to positive traffic development beyond forecasts and despite a substantial construction cost overrun. The second one is the combined bridge and tunnel project connecting Denmark and Sweden inaugurated in 2000. This project was haunted by a substantial construction cost overrun and a car traffic income shortfall (60\% lower than budget in 2001). The latter was partly explained by unexpected tactical responsive actions by competing ferry services.

At the first readings of L141 in the Danish Parliament on 18 March 2015, the spokesman of Venstre-The Liberal Party of Denmark said (using the metaphor of traffic lights): With the actual economic assumptions, the expected payback period is 39 years. This means that we are still in the green zone. The Liberal Party does not want to go into the yellow or red zone, thereby taking the risk that the taxpayers must pay part of the project. When asked about what lengths of the payback period he associated with the colored zones mentioned, he responded: We have the rule of thumb in the Liberal Party-and I think this is also the case elsewhere-that as long as we are under 40 years we are in the green zone, then we are on safe ground regarding the taxpayers avoiding to pay. When we are between 40 and 50 years we are in the yellow zone, then it begins to be on shaking ground. When we are over 50 years we are in the red zone and we must stay completely out of that one, that is what I mean (Lorentzen, 2015).

In accordance with these statements the uncertainty profiles in this paper are 
presented in terms of the three-color categories in order to facilitate a match with the preferences of the Liberal Party, that are generally shared among the majority of political parties. Although L141 was passed on 28 April by the Parliament without much debate, it became clear from the comments that there were three hurdles to be passed satisfactorily before the project can be launched politically. Firstly, an application about subsidies of the construction works of approximately DKK 11.3 billion should be positively responded to by the EU. (Rate of exchange: DKK $100 \approx 13.16 €$ ). Secondly, continuing negotiations with the building consortia concerning an expected construction budget overrun of DKK 8.9 billion should be successfully completed. Thirdly, the environmental project approval by the German authorities should be obtained. At the time of debate in the Parliament, it was assumed that all three issues would be resolved by September 2015. As it becomes clear from the following this is far from being the case.

The main objective of this paper is to produce scientifically sound evidence of the Fehmarn Belt immersed tunnel being a financially high risk business case. This is certainly challenging the official partial sensitivity analyses allowing the project proponents to claim robustness and low risk. By making uncertainty profiles available for the first time it is established that the risk of financial failure is much larger than hitherto known by the public community.

Section 2 of the paper presents a summary of the underlying work on which the actual uncertainty analysis of the Fehmarn Belt project is based. In Section 3 a series of official construction cost estimates is collected and discussed. Traffic forecasts are presented in Section 4 and critically discussed. In Section 5, the author presents and validates the financial model intentionally developed to match the official financial model not publicly available. The first uncertainty profile is presented in Section 6 and the second one in Section 7. Conclusions are found in Section 8 and future developments after the project has been put on hold are discussed in Section 9. An earlier version of the paper has been presented at a working seminar (Schjær-Jacobsen, 2016).

\section{Modelling of Risk and Uncertainty in Large Infrastructure Projects}

Recent research has revealed that large infrastructure projects are seldom realized within scheduled budget, time and specifications. Most often cost budgets are overrun, benefits falling short, time schedules are not met etc. Studies of discrepancies between ex ante estimation and ex post reality typically fall in two categories. The first category studies the discrepancy as a mere difference between the forecasted performance at the time of decision to build and the realized performance after project completion. Flyvbjerg and associates have done extensive research into the magnitude of discrepancies in large infrastructure projects. Basically, they offer two explanations for discrepancies, namely optimism bias and strategic misrepresentation. They propose to use reference class forecasting applied at the project level as a cure for optimism bias, (Flyvbjerg et al., 
2004; Flyvbjerg, 2006). According to this approach any ex ante estimation should be adjusted by an amount determined from a reference group of identical, or at least similar, projects already completed. In a later work, they present a more comprehensive analysis and offer prescriptive advice to cope with the strategic misinterpretation problem pertaining to various actors in the project processes (Flyvbjerg et al., 2009).

The second category of studies of discrepancies between ex ante and ex post project performance may be considered an extension to the first category: Not only is the discrepancy of project performance studied but also the ex ante uncertainty estimations compared to the ex post outcome (Lundberg et al., 2011).

A comprehensive modelling of uncertainty and risk may be accomplished by combination of two approaches, namely the probability approach and the possibility approach compared and documented in a series of research papers by the author. Initially interval analysis was proposed as a novel method for representation and calculation of uncertainty in terms of worst and best case analysis (Schjær-Jacobsen, 1996). Later on, the concept was extended to fuzzy numbers and probability distributions (Schjær-Jacobsen, 2002, 2004). Special attention was devoted to computational challenges using intervals and fuzzy numbers with non-monotonic performance functions (Schjær-Jacobsen, 2010). The concepts of aleatory and epistemic uncertainty were explicitly related to probabilistic and possibilistic representation of uncertainty, respectively (Schjær-Jacobsen, 2013). In (Schjær-Jacobsen, 2014) the propensity for overlooking uncertain but indeed possible outcomes with low likelihood of occurrence was focused on.

In the official financial report on the Fehmarn Belt project (Femern A/S, 2014b), uncertainty was handled by partial sensitivity analysis and stress tests on the main scenario and allocation of reserves. As is well known the former method is a local analysis based on arbitrary and small one-at-a-time changes of the uncertain variables and does not give the full picture of the consequences of the uncertainties involved. With a base case payback period (PBP) of 32 years, changes reported were all within the range $[-4 ;+9]$ years. As it becomes clear from the results in this paper the real uncertainties are much larger.

\section{Construction Cost Estimations}

Through the last years, a series of construction cost estimates of the fixed link crossing the Fehmarn Belt have been published, including those of the originally proposed sustained bridge solution (TRM, 2004). In this paper, we focus on the construction cost estimates released since November 2014, when a decisive momentum occurred for advancing the project for approval by Parliament based on an immersed tunnel concept.

Femern A/S announced a total construction cost exclusive of reserves to be DKK 7.3 billion for the Danish land works and DKK 40.5 billion for the coastto-coast tunnel work, totaling DKK 47.8 billion for the entire project leaving out German hinterland investments carried by Germany itself (Femern A/S, 2014b). As far as reserves are concerned the land works are subject to guidelines from 
the Ministry of Transportation requiring reserves of 30\% (TRM, 2006, 2010). The Ministry explains that the coast-to-coast tunnel works are not covered by the guide lines mentioned. Costing of the tunnel works are done in a dialogue process with the construction consortia and less reserves are apparently required; in this particular case $14 \%$ reserves are allocated. In this paper the designation Base Case $\mathrm{N}$ is introduced to identify the specific set of assumptions used in different calculations. The construction costs are summarized under the heading Base Case 0 in Table 1, identical to the initial Main Scenario (Femern A/S, 2014b). However, for reasons not known to this author, also 30\% reserves are used, see Base Case 1 in Table 1. Only a few months later a 22\% cost increase of the coast-to-coast construction work was announced (Femern A/S, 2015) due to new incoming bids from the construction consortia. However, the major part of the increase was absorbed by reducing the $30 \%$ reserves to only $11 \%$ without further explanation, see Base Case 1' and 2 in Table 1. Later on, in 2015 Femern A/S announced new negotiations with the construction consortia in an effort to reduce costs. No results, however, have been published so far.

Table 1. Project construction costs. Base Case 0: Main Scenario (Femern A/S, 2014b). Base Case 1: Total reserves 30\% (Femern A/S, 2014b, Table 20). Base Case 1' and 2: Coastto-coast construction costs increased by $22 \%$ (Femern A/S, 2015).

\begin{tabular}{|c|c|c|c|}
\hline $\begin{array}{c}\text { Construction costs } \\
\text { (DKK billion, } 2014 \text { level) }\end{array}$ & Base Case 0 & Base Case 1 & $\begin{array}{c}\text { Base Cases 1' } \\
\text { and } 2\end{array}$ \\
\hline \multicolumn{4}{|l|}{ Danish land works } \\
\hline Construction costs excl. reserves & 7.3 & 7.3 & 7.3 \\
\hline Correction allowance (10\%) & 0.7 & 0.7 & 0.7 \\
\hline Reserves (20\%) & 1.5 & 1.5 & 1.5 \\
\hline Sum reserves & 2.2 & 2.2 & 2.2 \\
\hline Sum reserves $(\%)$ & $30 \%$ & $30 \%$ & $30 \%$ \\
\hline Sum construction costs incl. reserves & 9.5 & 9.5 & 9.5 \\
\hline \multicolumn{4}{|l|}{ Coast-to-coast construction } \\
\hline Construction costs excl. reserves & 40.5 & 40.5 & 49.4 \\
\hline Reserve for contractor risk & 1.8 & 1.8 & 1.8 \\
\hline \multicolumn{4}{|l|}{ Other reserves: } \\
\hline Client reserve & 3.7 & 3.7 & 3.7 \\
\hline Extra reserves $(16.4 \%)$ & & 6.7 & \\
\hline Total other reserves & 3.7 & 10.5 & 3.7 \\
\hline Sum reserves & 5.5 & 12.3 & 5.5 \\
\hline Sum reserves (\%) & $14 \%$ & $30 \%$ & $11 \%$ \\
\hline Sum construction costs incl. reserves & 46.0 & 52.7 & 54.9 \\
\hline \multicolumn{4}{|l|}{ Total project } \\
\hline Total construction costs excl. reserves & 47.8 & 47.8 & 56.7 \\
\hline Total reserves & 7.7 & 14.5 & 7.7 \\
\hline Total reserves (\%) & $16 \%$ & $30 \%$ & $14 \%$ \\
\hline Total construction costs incl. reserves & 55.5 & 62.2 & 64.4 \\
\hline
\end{tabular}


It should be mentioned here that EU subsidies of DKK 10.3 billion were assumed in Base Case 0, 1 and 1' but only DKK 4.4 billion were granted by June 28,2015 on the condition that construction costs are incurred before a certain deadline. Still an option exists to apply for supplementary funding at a later time.

\section{Traffic Forecasts}

Traffic incomes from four categories are budgeted: Passenger cars, trucks, busses and trains. The traffic forecasts were carried out and reported (Intraplan Consult $\mathrm{GmbH}$ and BVU Beratergruppe $\mathrm{GmbH}, 2014 \mathrm{a}, 2014 \mathrm{~b}, 2015)$ assuming discontinuation of the existing Scandlines ferry service Rødby-Puttgarden and adopted in the subsequent analyses (Femern A/S, 2014a, 2014b). Graphs for passenger cars and trucks are shown in Figure 1 and Figure 2 by volume. Passenger car traffic is the most important category accounting for a major share of the total traffic income. It is also by far the most controversial income issue for several reasons. Firstly, a forecasted traffic jump of $66 \%$ by tunnel opening including a ramp-up period of 3 years, see Figure 1, has been seriously questioned (Andersen, 2015; DIW Econ GmbH, 2015a; LR Consulting, 2015a, 2015b). 40\% of the traffic jump is made up of transferred traffic from other existing ferry services calculated by means of the same traffic model as was used in earlier forecasting work (FTC, 1999, 2003). The remaining 60\% of the traffic jump is transferred traffic from the Great Belt link and could not be forecasted by using the same model but rather by loosely founded ad hoc arguments (Andersen, 2015). The external quality assurance report (COWI, 2015) commissioned by the Ministry of Transport explicitly stated in the main conclusion that "especially the expected transfer of passenger car traffic from the Great Belt is difficult to document due

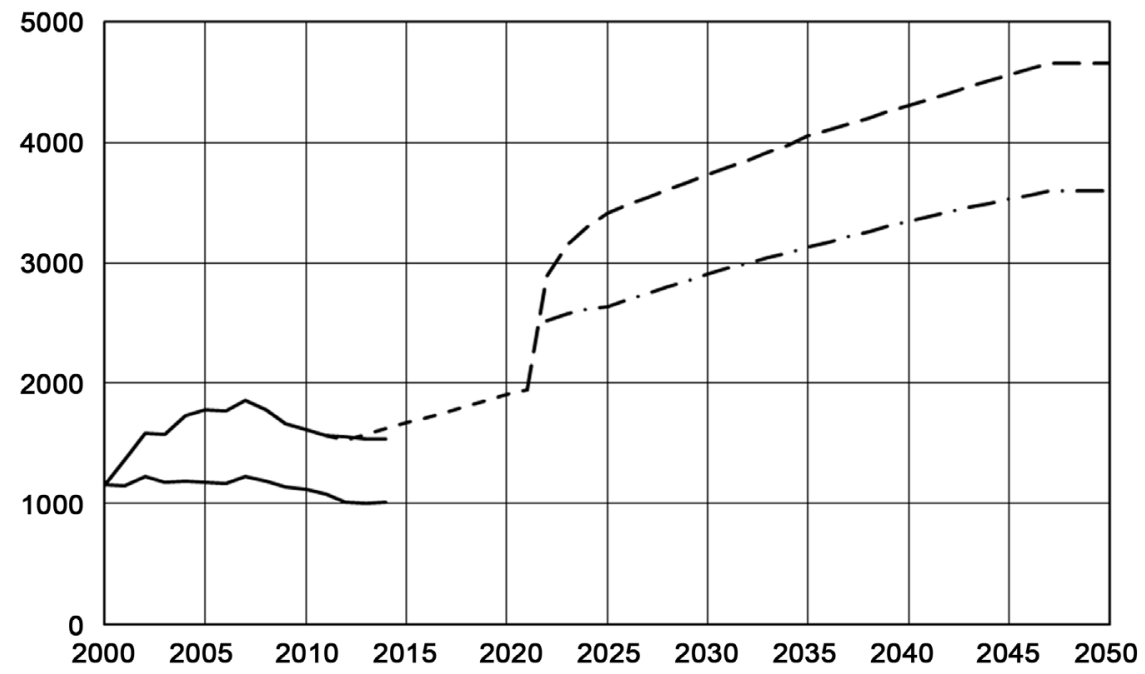

Figure 1. Fehmarn Belt passenger car traffic (1000 one way cars pr. year). 2000-2014, upper: Realized total cars by ferry (Statistikbanken, 2015). 2000-2014, lower: Realized non-shopping cars by ferry (Scandlines, 2015b). 2011-2021: Forecast total cars by ferry (Femern A/S, 2014a). 2022-2050+, upper: Forecast total cars by tunnel (Femern A/S, 2014a). Base Case 0, 1, 1’. 2022-2050+, lower: Forecast total cars by tunnel, (DIW Econ $\mathrm{GmbH}, 2015 b)$. Base Case 2. 


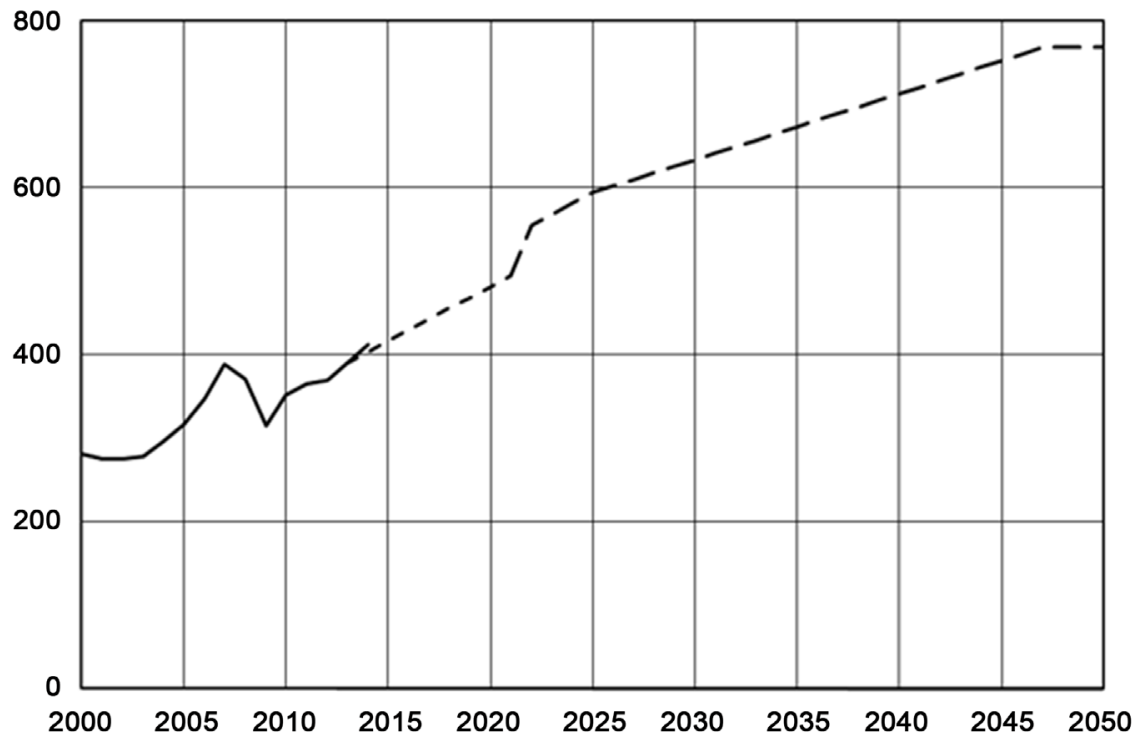

Figure 2. Fehmarn Belt truck traffic (1000 one way trucks pr. year). 2000-2014: Realized total trucks by ferry (Scandlines, 2015b). 2011-2021: Forecast total trucks by ferry (Femern A/S, 2014a). 2022-2050+: Forecast total trucks by tunnel (Femern A/S, 2014a). Base Case $0,1,1,2$.

to lack of data of the present traffic pattern crossing the Great Belt link" and further investigations are recommended. In a press release from the Ministry of Transport the Minister is quoted to say "COWI has found that the traffic prognosis is thorough and presents a realistic estimate of the tunnel traffic. This is an important conclusion and then we politicians can concentrate on the remainder of the project", (TRM, 2015). This statement suggests that the Minister chooses to ignore a serious reservation in the conclusion of the external quality assurance report.

Secondly, today's ferry traffic consists of two distinctly different passenger car segments. Approximately $34 \%$ of the total traffic is a border shopping segment of local Danish passenger cars developed since 2000 enjoying a substantial tariff reduction whereas $66 \%$ are ordinary travelers, mainly for holiday purposes, see Figure 1. In the simplified model calculations (Intraplan Consult $\mathrm{GmbH}$ and BVU Beratergruppe GmbH, 2014a), however, an average tariff has been used for the total traffic thereby introducing an overestimation of unknown magnitude in the traffic forecasts. It is clear that by using a too low tariff, i.e. the average tariff, the forecasted tunnel traffic tends to be too large due to an overestimated relative preference in comparison with other competing connections. Furthermore, it is seen from Figure 1 that the ordinary passenger car segment shows a decline since 2000 .

Thirdly, the total road traffic income in 2014 from the existing Rødby-Puttgarden ferry services is $19 \%$ lower (Scandlines, 2015a) than forecasted (Femern A/S, 2014a). The reason for this is a mix of too high estimations of passenger car volume and tariff, too high estimation of truck tariffs and too low estimation of truck volume. As for the volumes consult with Figure 1 and Figure 2. Also 
shown in Figure 1 is an alternative forecast of passenger car traffic with a reduced traffic jump claimed to be more realistic (DIW Econ GmbH, 2015b). This forecast is used in Section 7.

The assumption of discontinuation of ferry services by tunnel opening is highly controversial. The traffic forecasters (Intraplan Consult GmbH and BVU Beratergruppe $\mathrm{GmbH}, 2014 \mathrm{a}$ ) do not deem it financially viable for Scandlines to continue ferry services when the fixed link opens to traffic but acknowledge that this is disputed. By sensitivity calculation they estimate that by allowing a tariff reduction of $25 \%$ compared to the main scenario the passenger car and truck volumes will be reduced by $10 \%$ and $12 \%$, respectively, with a 2 -hour ferry service and $14 \%$ and $15 \%$, respectively, with a 1 -hour service. The corresponding pay back periods will be increased by 6 - 8 years according to partial sensitivity analyses (Femern A/S, 2014b). Scandlines, on the other hand, maintains that they will certainly develop a feasible strategy to continue ferry service on a permanent basis. It is argued (DIW Econ GmbH, 2015a) that the future competitive situation between ferry and tunnel is modelled much too static and simplistic and that the strategic options for continued ferry operation is far from being adequately analyzed. In a more detailed competitive analysis (DIW Econ GmbH, 2015b) it is concluded that by implementing suitable cost and tariff structures the ferry service will be able to continue and even make the tunnel operation financially non-viable. The controversy between Scandlines and Femern A/S continues. However, due to lack of data this particular uncertainty is not explicitly included in the present analysis but is one of the arguments for the traffic income uncertainty assumed in the uncertain profile of Base Case 1 (see later).

\section{Development and Validation of a Deterministic Financial Model}

In order to calculate uncertainty profiles a deterministic financial model is needed that is capable of reproducing the project payback period (PBP) compared to what was obtained by the official financial model (Femern A/S, 2014b, 2015) as a function of a vast range of input variables. The financial model includes such features as Danish land works and coast-to-coast construction costs, construction reserves, length of construction period, road and rail traffic volumes and rates, EU subsidies, inflation, nominal and real interest rates, depreciation, VAT, joint taxation with Sund \& Bælt Holding A/S. The author was denied access to the official model by Femern A/S. Consequently, the author had to develop and validate his own model without assistance from Femern A/S, who refused to cooperate based on "no resources available for validation of external models". The present financial model developed and validated by the author is extended to a time period of maximum 60 years after tunnel opening. Input data not explicitly quoted in this paper are available elsewhere (Femern A/S, 2014b, 2015).

The present financial model has been evaluated against previously calculated payback periods (PBP) obtained by the official financial model. Some results are shown here: 
Base Case 0: Present model: 31 years. Official model (Femern A/S, 2014b): 32 years.

Base Case 1: Present model: 37 years. Official model (Femern A/S, 2014b): 37 years.

Base Case 1': Present model: 39 years. Official model (Femern A/S, 2015): 39 years.

The present model developed by the author is estimated to have an absolute PBP accuracy of \pm 1 year and a relative accuracy of approximately $\pm 3 \%$ compared to results from the official financial model (Femern A/S, 2014b). This accuracy is estimated to be sufficient for obtaining results accurate enough to arrive at the conclusions presented in this work. Further improvement of the accuracy would require the positive cooperation of the original model owner, since some details of the official model is not accounted for in the official reports and therefore not transparent to an external analyst.

\section{Uncertainty Profile of Base Case 1}

This uncertainty profile is generated by three major independent and uncorrelated uncertain input variables to the financial analysis based on Base Case 1. Basically, uncertainty data (i.e. lower and upper bounds) should be delivered by the ones, that delivered the base cases, but as this is not the case, one must look for alternative sources in order to produce uncertainty analyses.

1) The officially forecasted deterministic base case income from road traffic is based on the traffic forecasts of passenger cars, trucks and busses as well as forecasts of the tariffs (see discussion in Section 4). However, there are different indications that the forecasted base case income is to be considered as best case as well. No one ever claimed that the income from road traffic could possibly be larger than forecasted, on the contrary. The income shortfall for ferry operation reported for 2014 is $19 \%$ (Scandlines, 2015), which is expected to increase to $30 \%$ at the time of tunnel opening. This means, that the traffic jump at tunnel opening will start at a much lower level than forecasted. Further, the uncertainty connected with the possible continuation of ferry service, although not explicitly quantified, will contribute to a reduction of road traffic income compared to the base case. Thus, it seems reasonable (i.e. not too pessimistic) to assume a worst case of $15 \%$ lower road traffic income compared to the deterministic forecast. Thus, uncertain road traffic income is represented by a uniform probability distribution with upper limit equal to the official forecast (Femern A/S, 2014b) and lower limit equal to $85 \%$ of this same forecast.

2) Uncertain coast-to-coast construction costs excl. reserves are represented by a uniform probability distribution with an upper limit equal to DKK 49.4 billion and a lower limit equal to DKK 40.5 billion. The limits are determined by the range of coast-to-coast construction cost reported so far (Femern A/S, 2014b, 2015). It seems reasonable to expect an outcome of the ongoing negotiations to be within these limits as a negotiated compromise. Note that the reserves are varying between $14 \%$ and $30 \%$ according to the praxis of reserve allocation officially used (compare with Table 1). 
3) Uncertain EU subsidies are represented by a uniform distribution with upper limit equal to DKK 10.3 billion and lower limit equal to DKK 4.4 billion. These limits are determined by the budgeted and realized EU subsidy so far. The final realized EU subsidy is expected to be within this range. It is possible to reapply for extra subsidies in addition to the DKK 4.4 billion already allocated, but no one expects ever to exceed DKK 10.3 billion.

Because of the structure of the uncertainty data for all three variables uniform probability distributions seem to be the natural choice. In other words, the base cases are coinciding with either the worst or best cases. The resulting Uncertainty Profile 1.1 obtained by Monte Carlo simulation (Palisade Corporation, 2013), is shown in Table 2. The likelihood of a Payback Period (PBP) in the green zone, i.e. $\mathrm{PBP} \leq 40$ years is only $7.5 \%$ whereas the yellow zone accounts for $55.9 \%$ and the red zone $36.6 \%$. This particular analysis reveals that we have a high-risk project with a critically low likelihood of an acceptable PBP below 40 years.

The probability distribution of PBP is shown in Figure 3. During the Monte Carlo simulation, outcomes may occur where the project is not paid back within the model limit of 60 years. Two cases are possible: 1) The project would have a finite PBP larger than 60 years had the model been extended beyond that period of time. 2) The project would never be paid back because of ever increasing debts. Both cases are represented as $\mathrm{PBP}=61$ years in Figure 3 .

By using the interval approach (Schjær-Jacobsen, 2010, 2013) best and worst cases of the uncertain payback period (PBP) may be obtained directly from the uncertain input variables by interval calculations (Hyvönen and de Pascale, 2000): Best case $\mathrm{PBP}=37$ years and worst case $\mathrm{PBP}>60$ years. By comparison with Figure 3 these results are seen to correspond with the results of the probability approach. Generally, this is not so in cases with many uncertain variables (SchjærJacobsen, 2014).

Table 2. Uncertainty Profile 1.1 based on Base Case 1. Green: PBP $\leq 40$ years. Yellow: 40 years $<$ PBP $\leq 50$ years. Red: 50 years $<$ PBP.

\begin{tabular}{|c|c|c|}
\hline Major Variables & Base Case 1 & Uncertainty Profile 1.1 \\
\hline Traffic income & $\begin{array}{c}\text { (Femern A/S, 2014b, } \\
\text { Section 5.3) }\end{array}$ & $\begin{array}{c}\text { Uniformly distributed } \\
\text { uncertainty factor on road } \\
\text { traffic income }[0.85 ; 1.0]\end{array}$ \\
\hline $\begin{array}{l}\text { Coast-to-coast construction costs } \\
\text { excl. reserves }\end{array}$ & DKK 40.5 billion & $\begin{array}{l}\text { Uniform distribution } \\
\text { DKK }[40.5 ; 49.4] \text { billion }\end{array}$ \\
\hline EU subsidies & DKK 10.3 billion & $\begin{array}{l}\text { Uniform distribution } \\
\text { DKK }[4.4 ; 10.3] \text { billion }\end{array}$ \\
\hline \multirow{3}{*}{$\begin{array}{c}\text { Payback period (PBP) } \\
\text { by Monte Carlo simulation }\end{array}$} & & Red: $36.6 \%$ \\
\hline & 37 years & Yellow: 55.9\% \\
\hline & & Green: $7.5 \%$ \\
\hline $\begin{array}{l}\text { Total construction costs } \\
\text { incl. reserves }\end{array}$ & DKK 62.2 billion & DKK $[62.2 ; 64.4]$ billion \\
\hline Total reserves & $30 \%$ & {$[14 ; 30] \%$} \\
\hline
\end{tabular}




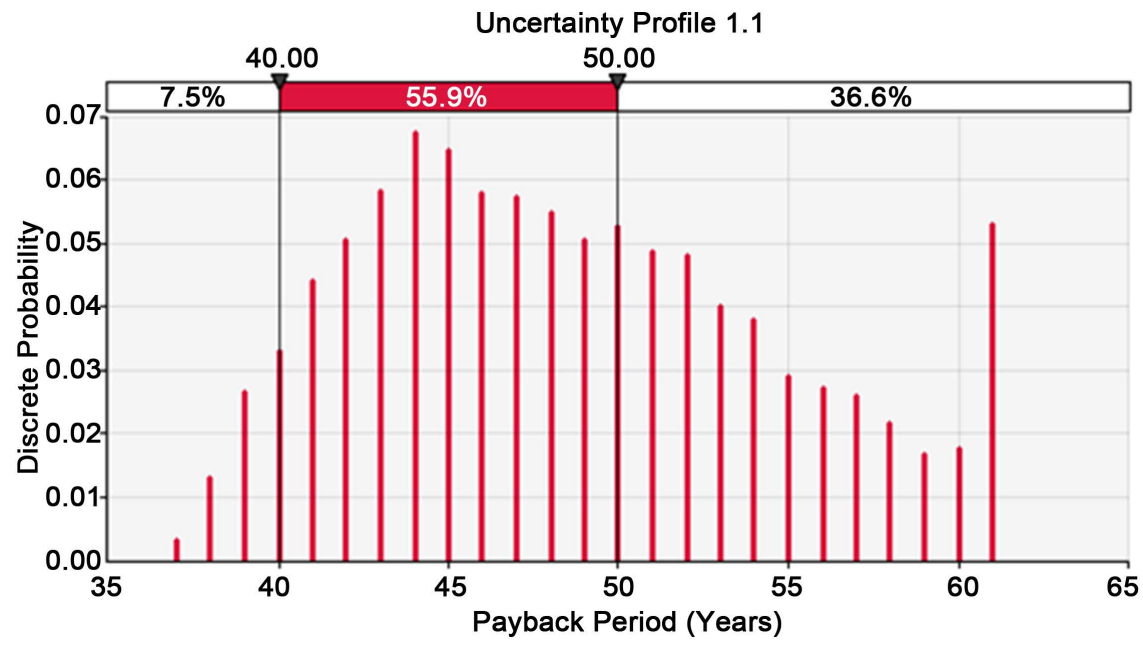

Figure 3. Probability distribution of Payback Period (PBP) by Monte Carlo simulation. Outcomes $\mathrm{PBP}>60$ years are registered as $\mathrm{PBP}=61$ years.

No partial sensitivity analysis was published for Base Case 1. However, thirteen different analyses are available for Base Case 0 (Femern A/S, 2014b). The individual changes of the $\mathrm{PBP}$ of 32 years for Base Case 0 are all within the range from -3 to +9 years, meaning that the PBP is ranging from 29 to 41 years. This represents a considerably smaller uncertainty compared to the Uncertainty Profile 1.1. What happens if two or more of the individual changes happen at the same time is unaccounted for in the official reports.

\section{Uncertainty Profile of Base Case 2}

This uncertainty profile is generated by three major independent and uncorrelated uncertain input variables to the financial analysis based on Base Case 2:

1) Uncertain passenger car traffic volume is represented by a triangular probability distribution with mode equal to the revised forecast depicted in Figure 1 (DIW Econ GmbH, 2015b). This alternative forecast is based on a less optimistic assumption concerning the traffic jump by tunnel opening due to revised estimates of the relative attractiveness of the tunnel connection compared to already existing ferry services. The upper limit is assumed 30\% larger and the lower limit $10 \%$ smaller as a rather conservative estimate of uncertainty. It is still assumed that the Rødby-Puttgarden ferry service by Scandlines will be discontinued by tunnel opening.

2) Uncertain coast-to-coast construction costs are represented by a uniform probability distribution with an upper limit equal to DKK 49.4 billion and a lower limit equal to DKK 40.5 billion. This uncertainty is similar to that of Uncertainty Profile 1.1.

3) Uncertain EU subsidies are represented by a uniform distribution with upper limit equal to DKK 10.3 billion and lower limit equal to DKK 4.4 billion. This uncertainty is similar to that of Uncertainty Profile 1.1.

The resulting Uncertainty Profile 2.1 obtained by Monte Carlo simulation (Palisade Corporation, 2013), is shown in Table 3. 
Table 3. Uncertainty Profile 2.1 based on Base Case 2. Green: PBP $\leq 40$ years. Yellow: 40 years $<\mathrm{PBP} \leq 50$ years. Red: 50 years $<\mathrm{PBP}$.

\begin{tabular}{|c|c|c|}
\hline Major Variables & Base Case 2 & Uncertainty Profile 2.1 \\
\hline Traffic income & $\begin{array}{l}\text { Passenger car traffic } \\
\text { volume (DIW Econ } \\
\text { GmbH, 2015b, Table 11) }\end{array}$ & $\begin{array}{c}\text { Triangularly distributed } \\
\text { uncertainty factor }[0.9 ; 1.0 ; 1.3]\end{array}$ \\
\hline $\begin{array}{c}\text { Coast-to-coast construction costs } \\
\text { excl. reserves }\end{array}$ & DKK 49.4 billion & $\begin{array}{l}\text { Uniform distribution } \\
\text { DKK }[40.5 ; 49.4] \text { billion }\end{array}$ \\
\hline EU subsidies & DKK 4.4 billion & $\begin{array}{l}\text { Uniform distribution } \\
\text { DKK }[4.4 ; 10.3] \text { billion }\end{array}$ \\
\hline \multirow[t]{2}{*}{$\begin{array}{c}\text { Payback period (PBP) } \\
\text { by Monte Carlo simulation }\end{array}$} & $\begin{array}{l}\text { Present model: } \\
>60 \text { years }\end{array}$ & $\begin{array}{l}\text { Red: } 87.7 \% \\
\text { Yellow: } 12.3 \%\end{array}$ \\
\hline & & Green: $0.0 \%$ \\
\hline $\begin{array}{l}\text { Total construction costs } \\
\text { incl. reserves }\end{array}$ & DKK 64.4 billion & DKK $[62.2 ; 64.4]$ billion \\
\hline Total reserves & $14 \%$ & {$[14 ; 30] \%$} \\
\hline
\end{tabular}

The results of Uncertainty Profile 2.1 show that the project is outside of the green zone, only marginally in the yellow zone by a likelihood of $12.3 \%$ and mainly in the red zone by a likelihood of $87.7 \%$. We have indeed a high-risk business case in the sense of a potential situation were the Danish Parliament will have to partially finance the project because of the guarantee issued.

As for the previous uncertainty profile, best and worst cases of the uncertain payback period (PBP) may be obtained directly from the uncertain input variables by interval calculations: Best case $\mathrm{PBP}=48$ years and worst case $\mathrm{PBP}>60$ years. Even the best case of 48 years is significantly above the acceptable limit of 40 years.

\section{Conclusion}

New financial uncertainty profiles of the Fehmarn Belt immersed tunnel have been derived and presented. The profiles are based on a deterministic financial model developed by the author to make the best possible match with the calculations of payback periods obtained by the official financial model which regrettably was not available to the author. By adopting the traffic light model proposed in the Danish Parliament and broadly accepted by the political community, it has been established that the uncertainty of the Fehmarn Belt tunnel payback period is much larger than the impression created by the tunnel proponents. The partial sensitivity analyses applied to the main scenario of November 2014 are shown to seriously underestimate uncertainty. Furthermore, official central estimates of construction costs and traffic forecasts are challenged. Realistic uncertainties based on readily obtainable facts about traffic volume and income, construction costs, reserves and EU subsidies have been imposed on a few but important input variables. Monte Carlo simulation has generated the probability distribution of the payback period allowing the green, yellow and red zone classification of likelihoods. It is shown that even external quality assurance of traffic 
forecasts is largely ignored when making specific reservations and recommendations.

Two uncertainty profiles have been presented neither of which is acceptable according to the criterion of producing a payback period of less than 40 years. The first one shows a likelihood of $7.5 \%$ of being in the green zone, $55.9 \%$ of being in the yellow zone and $36.6 \%$ of being in the red zone. Best and worst cases PBP are 37 and $>60$ years, respectively. The corresponding likelihoods of the second uncertainty profile are $0 \%, 12.3 \%$ and $87.7 \%$. Best and worst case PBP are 48 and $>60$ years, respectively. These results demonstrate that construction and operation of the Fehmarn Belt immersed tunnel is a high-risk business case in contrast to the official results obtained by partial sensitivity analysis carried out on the main scenario by November 2014.

\section{Future Developments}

The bulk of work reported in this paper was finalized by 6 January 2016. At that time the most recent official financial analysis was published by February 2015 (Femern A/S, 2015) and most recent partial sensitivity analysis by November 2014 (Femern A/S, 2014b). In addition to the uncertainties accounted for in the present paper major issues remain. Results of the negotiations with the coast-tocoast construction consortia since February 2015 are expected to result in reduced construction costs, an extended construction period and revised distribution of risks between project participants. The German reluctance to build the necessary traffic infrastructure and procedural complexities of finalizing the environmental approval procedure has already delayed the beginning of construction work and will delay completion of the tunnel as well. The issue of realistic traffic forecasts has not been satisfactorily resolved, in particular the option of continued ferry service and transfer of traffic from the Great Belt that may eventually lead to financial disaster of the fixed link. A revised official financial analysis has been announced by the Ministry of Transport to appear during the Fall of 2015 but has recently been delayed to be published in 2016, allegedly due to an ongoing external quality assurance process concerning coast-to-coast construction costs and allocation of reserves. Upon appearance of the revised financial analysis the uncertainty profiles presented in this paper may also be revised according to new data and information.

The analytical approach presented in this paper could easily be applied to evaluate the financial risk and uncertainty of megaprojects generally. It would give a more informative picture of project risks and uncertainties and would constitute a big leap forward compared to the partial sensitivity analysis currently applied, which inevitably underestimates real risks and uncertainties.

\section{References}

Andersen, K. E. (2015). Analysis of New Traffic Forecasts of the Fehmarn Fixed Link. Copenhagen: Praxis. (In Danish)

COWI (2015). External Quality Assurance of the Updated Traffic Prognosis of the Feh- 
marn Belt Project. Ministry of Transport. (In Danish)

Danish Parliament (2009). Planning of a Fixed Link Crossing Fehmarn Belt with Connecting Land Works in Denmark. Planning Act No. 285. (In Danish)

Danish Parliament (2015). Construction and Operation of a Fixed Link Crossing Fehmarn Belt with Connecting Land Works in Denmark. Proposal of Construction Act L141. (In Danish)

DIW Econ GmbH (2015a). Report on the Latest Traffic Forecast for the Fehmarn Belt Fixed Link. Berlin: Commissioned by Scandlines. (In German)

DIW Econ GmbH (2015b). How Robust Are the Profitability Analyses of the Fixed Fehmarn Belt Link? - Financial Model and Cost-Benefit Analysis on the Test Bench. Berlin: Commissioned by Scandlines. (In German)

Femern A/S (2014a). Traffic Forecast of a Fixed Link Crossing Fehmarn Belt. (In Danish)

Femern A/S (2014b). Financial Analysis of the Fehmarn Belt Fixed Link including Danish Land Works. (Official Translation of Original Danish Report).

Femern A/S (2015). Status of Construction Budget for the Fixed Link across the Fehmarnbelt. (Official Translation of Original Danish Document).

Femern A/S (2016). Official Home Page. www.femern.com

Flyvbjerg, B. (2006). From Nobel Prize to Project Management: Getting Risks Right. Project Management Journal, 37, 5-15.

Flyvbjerg, B., \& COWI (2004). Procedures for Dealing with Optimism Bias in Transport Planning. Guidance Document, British Department for Transport.

Flyvbjerg, B., Garbuio, M., \& Lovallo, D. (2009). Delusion and Deception in Large Infrastructure Projects: Two Models for Explaining and Preventing Executive Disaster. California Management Review, 51, 170-193. https://doi.org/10.2307/41166485

FTC (Fehmarnbelt Traffic Consortium) (1999). Fehmarn Belt Traffic Demand Study. Final Report.

FTC (Fehmarnbelt Traffic Consortium) (2003). Fehmarn Belt forecast 2002. Final Report.

Hyvönen, E., \& de Pascale, S. (2000). Interval Solver 2000 for Microsoft Excel. User's Guide, Version 4.0, Helsinki: Delisoft Ltd.

Intraplan Consult GmbH and BVU Beratergruppe GmbH (2014a). Fehmarnbelt Forecasts 2014-Update of the FTC-Study of 2002.

Intraplan Consult GmbH and BVU Beratergruppe GmbH (2014b). Fehmarnbelt Forecasts 2014-Update of the FTC-Study of 2002, Annex.

Intraplan Consult $\mathrm{GmbH}$ and BVU Beratergruppe $\mathrm{GmbH}$ (2015). Addendum to the Fehmarnbelt Forecasts 2014-Update of the FTC-Study of 2002 Referring to Additional Data and Statements Provided by Scandlines in January 2015.

Lorentzen, K. P. (2015). Quotation from Speech in the Danish Parliament on the Occasion of the First Readings of L141, Folketingstidende. (In Danish)

http://www.folketingstidende.dk/RIpdf/samling/20141/forhandlinger/M65/20141_M65 helemoedet.pdf\#nameddest=L141

LR Consulting (2015a). An Evaluation of the Project Economy for a Fixed Link Crossing Fehmarn Belt. (In Danish) www.lrc.dk

LR Consulting (2015b). Simulation of Effect of Changes in the Fehmarn Belt Project Forecast Assumptions for 5 Vital Parameters. (In Danish) www.lrc.dk

Lundberg, M., Jenpanitsub, A., \& Pyddoke, R. (2011). Cost Overruns in Swedish Transport Projects. Working Paper 2011:11, Sweden: Centre for Transport Studies, KTH Royal Institute of Technology.

Palisade Corporation (2013). @RISK, Version 6.1, Monte Carlo Add-In Module for MS 
Excel. www.palisade.com/risk

Scandlines (2015a). The Femern A/S Prognosis from November 2014 Compared to Factual Development. Letter from Scandlines ApS, Denmark, to the Danish Transport Commission. (In Danish)

Scandlines, (2015b). Scandlines Rødby-Puttgarden Traffic Volume 1998-2014. (In Danish) http://www.scandlines.dk/om-scandlines/fast_forbindelse.aspx

Schjær-Jacobsen, H. (1996). A New Method for Evaluating Worst- and Best-Case (WBC) Economic Consequences of Technological Development. International Journal of Production Economics, 46-47, 241-250. https://doi.org/10.1016/0925-5273(95)00159-X

Schjær-Jacobsen, H. (2002). Representation and Calculation of Economic Uncertainties: Intervals, Fuzzy Numbers, and Probabilities. International Journal of Production Economics, 78, 91-98. https://doi.org/10.1016/S0925-5273(00)00167-5

Schjær-Jacobsen, H. (2004). Modeling of Economic Uncertainty. Fuzzy Economic Review, 9, 49-73.

Schjær-Jacobsen, H. (2010). Numerical Calculation of Economic Uncertainty by Intervals and Fuzzy Numbers. Journal of Uncertain Systems, 4, 47-58.

Schjær-Jacobsen, H. (2013). Aleatory and Epistemic Modeling of Uncertainty for Quantitative Simulations. In E. Gil-Lafuente, et al. (Eds.), Decision Making Systems in Business Administration (pp. 373-383). Singapore: World Scientific.

https://doi.org/10.1142/9789814452052_0031

Schjær-Jacobsen, H. (2014). Modeling Economic Project Uncertainty: Beware of Best Practice. 18th Working Seminar on Production Economics, 4, 225-236.

Schjær-Jacobsen, H. (2016). Construction and Operation of the Fehmarn Belt Immersed Tunnel Is a High Risk Business Case. 19th Working Seminar on Production Economics, 1, 367-378.

Statistikbanken (2015). Passenger Car Traffic Rødby Færgehavn-Puttgarden. (In Danish) http://www.statistikbanken.dk/statbank5a/default.asp?w=1600

TRM-Danish Ministry of Transport (2004). Fixed Link across Fehmarnbelt-Financial Analysis.

TRM-Danish Ministry of Transport (2006). Document No. 16 Communicated to the Finance Committee from the Minister of Transport, Denmark. (In Danish)

TRM-Danish Ministry of Transport (2010). New Budgeting in the Ministry of Transport, Including Model of Financial Control and Risk Management for Construction Projects. (In Danish)

TRM-Danish Ministry of Transport (2015). Quotation of the Minister of Transport in Press Release 12 November. (In Danish) 
Submit or recommend next manuscript to SCIRP and we will provide best service for you:

Accepting pre-submission inquiries through Email, Facebook, LinkedIn, Twitter, etc. A wide selection of journals (inclusive of 9 subjects, more than 200 journals)

Providing 24-hour high-quality service

User-friendly online submission system

Fair and swift peer-review system

Efficient typesetting and proofreading procedure

Display of the result of downloads and visits, as well as the number of cited articles Maximum dissemination of your research work

Submit your manuscript at: http://papersubmission.scirp.org/

Or contact jfrm@scirp.org 